\title{
PASCA PERISTIWA \\ "NOMOR TELEPON DARURAT AS"
}

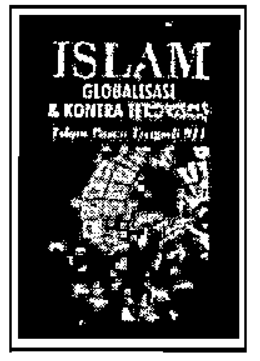

Judul

: Islam, Globalisasi \& Kontra Terorisme. Islam Pasca Tragedi 911

Penulis : : Prof. Dt. Juhaya S. Praja

Cetakan : I September 2004

Penerbit : Kaki Langit

Tebal : xvii +320

Dalam filsafat, kebenaran merupakan hasil konsensus. Di luar benar dan tidaknya statemen ini, nampaknya dari tahun ke tahun dan dari periode ke periode babakan sejatah manusia, ada pergeseran atau transfotmasi makna hampit ada pada setiap kata dalam bahasa manapun. Kata "Allah" misalnya, sebelum kedatangan agama Islam, kata ini sudah sejak lama digunakan oleh bangsa Arab untuk menamakan salah satu Tuhan yang diakui oleh sebagian masyarakat. Masyarakat Mekkah yang pada waktu itu secara umum mengakui adanya tiga tuhan yaitu manat, latta dan uzza, juga telah mengenal kata "Allah". Salah satu buktinya adalah nama orang tua Nabi Muhammad yaitu "Abdullah." Entah apa yang dimaksud dengan nama Abdullah tersebut, yang jelas makna dari kata "Allah" tersebut bukanlah untuk menamai Tuhan Yang Esa, karena secara umum pada waktu itu masyarakat Mekkah mengakui adanya tiga tuhan yang masing-masing mereka berinama dan tidak satu pun yang bernama Allah. Namun setelah kedatangan agama Islam, kata "Allah" tersebut dimaknai sebagai nama Tuhan Yang Esa.

Dari kasus ini jelas bahwa suatu kata dalam bahasa manapun selalu mengandung unsur pemaknaan secara spesifik dan tergantung pada siapa yang memaknainya. Salah satu bukti tersebut adalah pada kata "Allah" di atas. Hingga saat ini, kata "Allah" bagi masyarakat Islam adalah sebuah nama bagi Tuhan Yang Esa dan yang mereka akui. Namun bagi sekelompok masyarakat lainnya, khususnya Nashrani (Kristen), kata "Allah" merupakan nama untuk tuhan bapak sebagaimana keyakinan mereka. Inilah yang membuktikan statemen pertama di atas. Walaupun dianggap salah oleh kelompok lain dan diakui kebenarannya oleh sekelompok masyarakat lainnya, tetap saja bagi masyarakat Islam, Allah adalah Tuhan Yang Esa dan satu-satunya Tuhan di alam ini.

Terlepas dari itu semua, kembali pada filosofi tentang kebenaran, bèberapa 
tahun terakhir ini sebuah kata yang mungkin amat populer adalah kata "terorisme." Secara historis, tidak diketahui secata pasti kata ini mulai kapan muncul, namun menjadi populer setelah terjadinya serangan sebelas September 2001 di Amerika Serikat yang telah menjadi perhatian besar penduduk dunia. Kalau di Indonesia, kata "terorisme" merupakan kata adaptif dari bahasa bangsa lain, sebut saja bahasa Inggris misalnya kata "terorism". Jika dicari akar dari kata ini harus kembali pada kata asalnya, sehingga pemaknaan atas kata ini juga akan diketahui. Di luar benat dan tidaknya dari pemaknaan tersebut atau masih adanya makna-makna lainnya yang juga diakui oleh kelompok masyarakat tertentu, yang jelas kata ini telah "memakan korban" begitu banyak orang dan telah meluluhlantakkan sebagian isi bumi. Untuk melihat berbagai macam pemaknaan (baca: pendefinisian) atas kata “terorisme" ini, terutama pasca peristiwa sebelas September 2001, termasuk efek dan akibatnya dapat dibaca dalam buku "Islam, Globalisasi \& Kontra Terorisme. Islam Pasca Tragedi 911.”

Terlihat awal tulisan ini "jauh panggang dari api" karena yang dibahas adalah pemaknaan kata tetorisme sedang judul yang diajukan adalah pasca tragedi nomor telepon darurat AS. Mungkin pembaca bertambah bingung dengan ini, namun coba perhatikan paparan paragraf-paragraf di bawah ini yang merupakan sekelumit cuplikan dari buku yang judulnya telah disebutkan di atas dan merupakan buku pokok dalam kajian ini.

Pertama, kenapa nomor telepon darurat (emergency pbone number) Amerika Serikat? Tragedi serangan yang disebut Amerika sebagai kelompok teroris terjadi pada tanggal sebelas (11) September tahun 2001. Kasus yang banyak menelan korban lebih dari enam ribu jiwa termasuk ratusan orang Islam sendiri (p. 52) lebih populer dengan metode penulisan atau penyebutan dengan istilah tragedi 911 . Nomor 911 baik secara langsung ada kaitannya atau tidak dengan peristiwa tersebut merupakan nomor telepon darurat di seantero negara Amerika Serikat (p. 51). Oleh karena itu, peristiwa runtuhnya gedung Word Trade Centre (WTC) Amerika Serikat ini sering juga disebut dengan istilah peristiwa 911 yang nomor itu merupakan nomor telepon darurat di seantero negata adidaya yang mengaku sebagai "polisi dunia" tersebut. Menurut buku tersebut, nomor 911 memang ada kaitannya yaitu bahwa tanggal dan bulan penyerangan memang sengaja dilakukan pada nomor yang menunjukkan keadaan darurat negara Amerika (p. 51).

Kedria, dengan adanya tragedi 911 telah melahirkan istilah multi nasional yaitu kata "terorisme". Setelah peristiwa yang menyebalkan bagi presiden Amerika Serikat, Goerge W. Bush, ini sekian banyak pakar berbagai bidang keilmuan dan di betbagai penjuru dunia menulis, menganalisa, meneliti dan seterusnya tentang peristiwa tersebut dan menyebut pelakunya sebagai kelompok tetoris. Akhinnya populetlah

${ }^{1}$ Kompas, 29 Oktober 2002. 
istilah "terorisme" di hampir seluruh penjuru dunia ini. Dengan populernya istilah ini maka lahirlah berbagai pemaknaan atas kata tersebut'. Baik itu yang menjustifikasi kebenarannya maupun yang menolaknya selain juga bagi mereka yang tidak mempedulikannya. Buktinya? Para sarjana mempunyai definisi terorisme sesuai dengan sudut pandang dan keahlian masing-masing. Walaupun hampir sama dengan definisi terorisme menurut penguasa baik lokal maupun nasional, namun secara mendasar mereka mempunyai pandangan sesuai keahliannya sendiri-sendiri.

Menurut kelompok sarjana ini secara umum kata terotis dapat diartikan sebagai premediated threat or used of violence by subnational groups or cladenstine individuals intended to intimidate and coerce governments, to promote political, relegious or ideological outcomes, and to inculcate fear among the public at large ${ }^{3}$ FBI selama beberapa tahun hingga kini masih mendefinisikan terorisme sebagai the unlawful use of forte or violance againts person or property to intimidate or to coerce a gaverment, the civilian population, or any segment thereof, in furtherance of political or social goals. Di sisi lain, Robert Kenleey yang dapat dibilang sangat kritis tidak menyetujui definisi-definisi sebagaimana di atas. Ia lebih jauh memberikan contoh Amerika yang mendukung gerakan gerilya melawan pemerintah Nicaragua sedangkan sebaliknya Amerika melakukan hal sebaliknya terhadap gerakan yang sama di El Salvador. Dengan pemberian contoh ini kemudian ia mempertanyakan apakah "terorisme" dapat diartikan sebagai perbuatan kejahatan dalam mendukung tujuan politik? Atau apakah hal semacam itu dapat dikecualikan apabila dilakukan oleh pemerintah? Bagaimana bila terorisme disponsori oleh pemerintah? Dengan pertanyaan-pertanyaan Robert Kenleey semacam ini, ia sebenarnya tidak mendukung begitu saja definisi terorisme yang diberikan oleh para teman-temannya di Amerika (pp. 30-31).

Juhaya S Praja dalam buku ini tidak memberikan definisi yang jelas tentang terorisme. Ia hanya mengatakan bahwa tetorisme bisa muncul karena ajaran agama atau karena motivasi agama. Atau terorisme muncul karena seorang teroris menganggap bahwa dirinya adalah korban dari suatu rezim yang represif dan bypocritical dan tidak mau memahami keadaan mereka seperti yang dialami oleh IRA, EPTA dan lainnya (p. 31).

Di luar itu semua, dalam kelompok yang disebut banyak kalangan sebagai teroris sendiri juga mendefinisikan terorisme secara berbeda. Sebut saja Imam Samudra yang menulis buku $A k u$ Melayan Teroris, lalu istri Ali Imron yang menulis buku dengan judul Orang Bilang Ayabku Terrris. Mereka memang tidak mendefinisikan kata teroris. Namun teroris yang meteka jadikan judul dalam bukunÿa bermaksud

\footnotetext{
${ }^{2}$ Najmuddin Ramly (2003), Paradokes Penangan Terorisme, Republika Online http \Iwrvwrepublika. co.id.htm.

${ }^{3}$ Whittaker (2000), Terorisme: Understanding Global Threat, New York: Longman London, pp. $91-$ 124.
} 
menyebut Amerika Serikat dan sekutunya. Mengapa demikian, kedua penulis yang berseberangan dengan umum ini sebenarnya ingin mengatakan bahwa definisi teroris jangan hanya terpaku pada definisi yang diusung negara Barat saja. ${ }^{4}$

Ketiga, kenapa pasca tragedi? Setelah tragedi ini, banyak hal yang mempengaruhi kondisi dunia, baik politik, sosial, ideologi, dan hubungan keagamaan secara intemasional. Lihat saja; serangan ke Afganistan, Irak lalu bom Legian Bali, seminar-seminar terorisme, Jama'ah Islamiyah, pondok pesantren dan seterusnya ${ }^{5}$. Disepakati atau tidak, yang jelas dengan adanya peristiwa 911 seakan wajab dunia telah berubah. Banyak negara yang merubah kebijakan mereka, banyak negara yang menjadi luluh lantak dibombatdit negara lain, banyak masyarakat yang kelaparan dan seterusnya. Bahkan bukan hanya itu, ada sebagian kecil umat beragama yang minoritas di sebuah negara harus "menanggung" akibat dari peristiwa tersebut. Tinta merah aksi terorisme pun terus menerus tettoreh dalam lembaran sejarah dunia modem, Tiger di Srilanka, Takfir wal-Hijtah di Mesir, Baader-Meinhof di Jerman, Red Brigdes di Italia, Action Directe di Prancis, Irish republican Army di Inggris, Tupak Amaru di di Peru, Aum Shinri Kyo di Jepang dan yeng terakhir adalah kelompok Al-Qaidah Afghanistan. ${ }^{6}$

Pasca tragedi 911 memang menyisakan berbagai hal. Ada yang mengatakan bahwa terminologi Clash of Civilization yang diusung oleh Samuel P. Huntington di awal melenium III ini $^{7}$. Ada juga yang berseberangan dengan tesis tersebut juga memberikan betbagai alasan. Di sisi lain, ada yang mengatakan bahwa Perang Salib telah ditabuh kembali genderangnya ${ }^{8}$. Dan masih banyak lagi pendapat, peristiwa, anggapan, serta lain-lainnya pasca tragedi tersebut.

Inilah sekelumit diskusi isi buku yang kami sebutkan judulnya di atas. Buku yang ditulis oleh Juhaya S. Praja, sebagaimana diakui sendiri dalam pengantarnya, merupakan hasil penelitian yang dilakukan di Amerika Serikat jauh sebelum peristiwa tetsebut dan penelitian kedua pasca peristiwa itu. Entah karena menemukan momentumnya, kemudian penelitian keduanya dilakukan atau karena alasan lain, penulisnya tidak menyebutkan dalam buku ini.

Secara umum isi dari buku ini terangkum dalam kata pengantat penulisnya. Dari bagian satu yang merupakan hasil penelitianya jauh sebelum peristiwa 911

+ Edward S. Herman (1982), The Real Teror Network: Terrorime in Fact in Propaganda, Boston: South End Press, pp. 76-79.

\$Najamuddin Ramly, Op. Cit.

"Alwi Shihab (2004), Membedah Islam di Barat: Mentepis Tudingan Meluruskan Kesalabpabaman, Jakarta: PT. Gramedia Pustaka Utama, p. 5.

${ }^{7}$ Samuel P. Huntington (1996), The Clash of Civilization and the Remaking of 'World Order, New York: Touchtone Books, p. 15.

s Sunardi dan Abdul Wahid (2004), Kejabatan Terorisme Perspektif Agama, HAM dan Hukum, Bandung: PT' Refika dditama, p. 21. 
hingga hasil akhir penelitian keduanya pasca peristiwa tersebut diuraikan secara singkat, padat dan jelas. Mungkin, pembaca buku ini untuk mengetahui isinya secata umum tidak perlu lagi membaca isinya, karena sudah dirangkum dalam kata pengantarnya. Namun bagi yang menghendaki penjelasan mendetail memang harus dan perlu membaca isinya secara keseluruhan.

Ada beberapa hal yang harus dijelaskan, karena di sisi lain, bagian-bagian dalam buku ini merupakan tulisan lama penulis yang juga pernah menjadi buku tersendiri. Khususnya adalah bagian pertama dan itu telah diakui penulis sendiri dalam kata pengantarnya. Kelemahan lainnya adalah bahwa buku ini cenderung memihak pemerintah atau arus umum. Muskipun ia juga menguraikan beberapa pendapat yang bertentangan dengan arus umum, namun penulisnya sendiri tidak pernah berpendapat tentang apa definisi terorisme itu sendiri.

Untuk memperjelas statemen ini dapat kita lihat arus umum tentang terorisme tersebut. Berikut contohnya; definisi terorisme yang tidak jauh berbeda dengan yang diungkapkan Hussein Alatas. Menurut Hussein Alatas, teroris (pengganas) adalah mereka yang merancang kekuatan sebagai senjata persengketaan terhadap lawan dengan serangan kepada manusia yang tidak terlibat, atau harta benda tanpa menimbang salah atau benar dari segala agama atau moral, berdasarkan atas perhitungan bahwa segalanya itu boleh dilakukan bagi mencapai tujuan matalamat persengketaan."

Selain itu, penulis kurang memperhatikan agama Islam sebagai agama mayoritas penduduk Indonesia. Di Indonesia yang mayoritas Islam sebagai pembaca buku ini tidak dijelaskan pemahaman mereka tentang masalah yang dikaji. Padahal dalam dunia Islam Indonesia yang paling menarik untuk dipaparkan dan ditunjukkan adalah terorisme negara yang diketuai Amerika Serikat sendiri. Bukti-bukti seperti kekuatan imperialisme AS dan sekutunya menekan negara-negara lemah (contohnya Indonesia) dalam bidang ekonomi dan politik, politik aktif untuk melakukan intervensi langsung dan terbuka dalam permasalahan di Amerika Tengah dan Selatan: Kuba, Nikaragua, Panama, Chili, Guatamela, Salvador, Grenada, dan terjunnya dalam beberapa perang besat, membiayai tindakan-tindakan militer massa yang menyebabkan tibuan orang meninggal di tangan pemerintahan negara yang 'bersahabat' dengan mereka, menggulingkan pemerintahan (Iran, Isael) ${ }^{10}$ luput dari kajiannya. Coba saja bandingkan dengan Michael Barratt-Brown yang mengatakan bahwa imperialisme Amerika Serikat tidak ditagụkan lagi masih merupakan kekuatan paling besar dalam kaitan ekonomi, politik, dan militer yang dengannya negeri-negeri yang secara ekonomi kurang berkembang tunduk pada mereka yang secara ekonomi

${ }^{9} \mathrm{http} / /$ venus.igalaksi.com/warisan/amerika02j8.htm.

${ }^{10}$ Edward W. Said (1996), Kebudayaan dan Kekuasaan: Membongkar Mitos Hegemoni Barat, Bandung; Mizan, p. 377. 
lebih berkembang."1 Padahal kebrutalan Amerika Serikat ini sudah berjalan cukupa lama dan jarang dipaparkan pada masyarakat Indonesia yang mayoritas penduduknya muslim.

Tentang judul yang digunakan juga demikian, para pembaca mungkin akan bertanya-tanya karena judul besarnya adalah kata Islam dan itu juga digunakan dua kali. Islam sebagai agama atau orang yang beragama Islam (muslim) atau Islam sebagai ideologi yang juga digunakan oleh mereka yang dianggap sebagai "teroris". Semuanya masih menyimpan tanda tanya, karena penulisnya tidak menguraikan maksud dari judul buku yang diberikan. Menurut hemat penulis, judul buku ini hanya berusaha menemukan momentumnya saja dan tampa membetikan maksud apa-apa darinya. Karena pembahasan di dalamnya lebih banyak pada kondisi umat Islam dan itu juga terbatas di Amerika Serikat saja yang dibahas. Sedangkan ajaran Islam yang terus berkembang pasca peristiva tersebut tidak begitu banyak dibahas di dalamnya.

Hal ini dapat kita amati dari beberapa tulisan baik di media massa maupun dalam bentuk buku serta aksi-aksi "fundamentalis" yang menjelaskan tentang fenomena terorisme. Pasca Perang Dingin (the Cold War) terorisme mencuat sebagai salah satu dari empat isu yang paling menantang, menyedot perhatian dunia, dan juga merundung Indonesia. Adapun tiga isu lainnya adalah penyebaran senjata pemusnah massal, kejahatan berskala transnasional dan lalu lintas perdagangan narkotika. ${ }^{12}$ Pernyataan ini sangat benar ketika di tingkatan internasional, termasuk Indonesia, setiap kali terjadi aksi "terorisme" para tersangkanya sering terburu-buru dialamatkan kepada orang Islam. ${ }^{13}$

Globalisasi yang dinyatakan dalam judul buku ini juga tidak dispesifikasikan oleh penulis dalam pembahasan di dalamnya. Globalisasi apakah yang dimaksud, tidak pernah jelas. Sebagaimana diketahui bahwa globalisasi sangatlah general, apakah itu globalisasi ideologi, agama atau juga ekonomi ${ }^{14}$. Khusus yang terakhir ini,

${ }^{11}$ Michael Barratt-Borown (1970), After Imperialism, New York: Humanities, p. viii

${ }^{12}$ Landry Haryo Subianto (2002), "Indonesia and the Issue of Terrotism" dalam Kultur, Volume 2, No. 1, Jakarta: PBB UIN, pp. 115-127.

${ }^{13}$ Dalam beberapa aksi teror terakhir di Indonesia, melalui berbagai investigasi yang teliti dan lama, pelakunya memang adalah otang pemeluk Islam, yang menggunakan keketasan dengan justifikasi Islam. Namun, jika kemudian muncul pandangan yang mengidentikkan Islam sebagai agama teroris, hanya berdasar pada argumen terdapatnya sejumlah otang Islam yang melakukan teror atas nama agama, maka pandangan tetsebut sama sekali kelitu, berbahaya dan tidak bertanggung jawab. Beberapa tragedi bom yang melanda Indonesia adalah di Legian Bali (12 Oktober 2002), Bom di Hotel JW Marriot Jakarta (5 Agustus 2003), di depan kedubes Australia, Jakatta (9 September 2004), Bom Bali 2 (Oktober 2005).

14 Globalisasi ekonomi merupakan bagian besar cerita bagaimana perusahaan multinasional mengambil alih peran negara dalam menentukan jalannya perekonomian dunia. Selain itu, globalisasi ekonomi juga pemenuhan kepentingan sektor swasta, terutama perusahaan multinasional. Lihat $\mathrm{Ali}$ Sakti (2002), "Kegagalan Ekonomi Global" dalam Republika Onlise 
globalisasi ekonomi, memang tidak tersentuh sedikitpun, namun di sisi lain, penulis buku tidak pernah menjelaskan globalisasi apa yang dimaksudkannya, baik itu yang ada dalam judul maupun pembahasan di dalamnya. Inilah sisi lain kekurangan yang mungkin luput dari sorotan penulisnya. Padahal secara mendasar berbagai tindakan ekonomi Amerika Serikat dalam globalisasi ekonomi sangat signifikan. Contohnya adalah data yang mencatat bahwa Amerika Serikat menerima total dana sebesar lima triliun dolar dari negara lainnya termasuk dari dunia Arab. ${ }^{15}$

Imam Muttaqien

Pemerbati, penulis dan penerjemah beberapa buku, salab satunya adalab "Perebutan Kekuasaan Khalifah" yang diterbitkan Safina Insania Press Yogyakarta. E-mail: gus_iem@yaboo.com

\section{DAFTAR PUSTAKA}

\section{Ali Sakti (2002), Kegagalan Ekonomi Global. dalam Republika Online}

Alwi Shihab (2004), Membedab Islam di Barat: Menepis Tudingan Meluruskan Kesalabpahaman, Jakarta: PT. Gramedia Pustaka Utama.

Barratt-Botown, Michael (1970), After Imperialism, New York: Humanities. Edward Said W. (1996), Kebudajaan dan Kekuasaan: Membongkar Mitos Hegemoni Barat, Bandung; Mizan.

Herman, Edward S. (1982), The Real Teror Network: Terrorisme in Fact in Propaganda, Boston: South End Press.

${ }^{15}$ Kelicikan Amerika Serikat dalam globalisasi ekonomi antara lain; Dunia disuruh menabung pada Amerika Serikat dan meteka yang menikmatinya dengan bebas. Amerika Serikat dalam penjelantrahan globalisasi ekonomi selalu menganjurkan konsumsi (spending), negara lain ditaksit belanja dua miliar dolat pet hari. Hanya dengan cara itulah ekonominya berjalan, industri berjalan, kesempatan kerja tersedia. Amerika Serikat melakukan investasi di India kurang dari separoh jumlah yang diinvestasikannya di Amerika. India menginvest di Amerika sebesar 50 miliar dolar, sedangkan investasi Amerika di India hanya 20 miliar dolat. Dengan cara ini Amerika membuat dunia tergantung kepadanya: Pertama, tergantung dalam hal sifat boros/konsumsi Amerika dalam bentuk konsumsi dan impor. Indonesia misalnya tergantung pada impor Amerika antara 12-15 persen. Jepang, Cina, India dan negara lain nengumpulkan uangnya sedikit demi sedikit, menahan.konsumsi dan menyerahkannya kepada Amerika untuk dinikmati. Kedua, dunia tergantung pada ekonomi Amerika khususnya Pasar Modal serta dolannyanya agar investasi, hasil menabung, dan kekayaannya tetap aman. Yang lebih tidak menentu lagi adalah dolar yang beredar di luar Amerika (Euro-dollar atau $A$ sia-dollar) yang dikabarkan tidak bisa dikontrol lagi sehingga menjadi kekayaan Amerika yang sangat likuid untuk menarik kekayaan negara negara lain. Hal ini terjadi karena pengakuan dan penggunaan dolar Àmerika dalam berbagai tarnsaksi keuangan oleh masyarakat. Lihat Sofyan Safri Harahap (2004), Ekonomi Is/am: Spending atau Saving?, http://majelis.mujahidin.or.id /new/ kolom/ekonomi. 
http://venus.igalaksi.com/warisan/amerika02j8.htm

Huntington, Samuel P. (1996), The Clash of Civilization and the Remaking of World Order, New York: Touchtone Books.

Kompas, 29 Oktober 2002.

Landiry Haryo Subianto (2002), "Indonesia and the Issue of Terrorism" dalam Kultur, Volume 2, No. 1, Jakarta: PBB UIN.

Ramly, Najmuddin (2003), Paradoks Penangan Terorisme, Republika Online bttpwinn_republika_co_id.htm

Sofyan Safri Harahap (2004), Ekonomi Islam: Spending atau Saving? http:// majelis.mujahidin.or.id /new/kolom/ekonomi

Sunardi dan Abdul Wahid (2004), Kejabatan Terorisme Perspektif Agama; HAM dan Hukum Bandung: PT Refika Aditama.

Whittaker (2000), Terorisme: Understanding Global Threat, New York: Longman London. 